\title{
THE INFLUENCE OF THE FOODSTUFFS UPON THE SUSCEPTIBILITY OF THE LIVER TO INJURY BY CHLOROFORM, AND THE PROBABLE MECHANISM OF THEIR ACTION ${ }^{1,2}$
}

\author{
By SAMUEL GOLDSCHMIDT, HARRY M. VARS, AND ISIDOR S. RAVDIN
}

(From the Department of Physiology and the Harrison Department of Surgical Research, School of Medicine, University of Pennsylvania, Philadelphia)

(Received for publication January 12, 1939)

In a previous publication, data were presented which show that anesthesia produced by the inhalation of chloroform or divinyl ether, volatilized by a stream of oxygen, results in much less damage to the liver of the dog than when air is used as the volatilizing agent (1). Evidence already presented (2) reveals, in the dog, no difference in the rate or the degree of discharge of hepatic glycogen, or the height to which the blood sugar rises, or the amount of fatty infiltration, when the chloroform is volatilized with air or with oxygen, provided a very marked anoxemia does not exist. The protective action of oxygen appears not to be associated with these metabolic changes.

In the course of this work our attention was directed to the relation of the dietary to the susceptibility of the animals to liver damage by chloroform, and thus to the present investigation. That a diet high in carbohydrate is protective, and that a diet high in fat induces maximal susceptibility of the hepatic cells, when the liver is exposed to chloroform, has received much confirmatory support since first reported by Opie and Alford in $1914(3,4,5,1)$. Diets rich in protein have, also, been found to be protective against the necrotizing action of chloroform. Its value has been regarded as either inferior $(3,4)$, or at least equal to (5) a carbohydrate diet, in ameliorating the deleterious effects of chloroform.

Fasting also intensifies to a great degree the susceptibility of the hepatic cells to injury by chloroform, comparable to (4), or exceeding (5) that which results from a high fat intake.

It should be emphasized that our present studies and discussion do not include the late effects

\footnotetext{
1 Preliminary reports of part of the data in this paper were made before the Physiological Society of Philadelphia (Am. J. M. Sc. 1937, 193, 578), and the American Society for Experimental Pathology, April 1, 1938.

2 This investigation was aided by a grant from the Merck Fund for Surgical Research.
}

of poisoning by chloroform. The histological evidence of hepatic injury, twenty-four hours following the anesthesia, is, for the most part, our sole criterion of the effect of the chloroform. Thus, we are dealing with its primary effects; later, secondary factors may enter the picture as shown by Minot and Cutler (6).

Since the liver is the organ conspicuously attacked by chloroform, it is reasonable to assume that the composition of the hepatic cells determines their susceptibility to injury. Moise and Smith (5a) emphasized the desirability, in experiments of this type, of establishing a " nutritive equilibrium" in the animal on the ration in question before producing the tissue injury. In the present experiments, not only have the diets been adequate and feeding prolonged, but, also, the hepatic glycogen and lipid concentrations have been determined analytically on control animals before, and on the experimental animals after, anesthesia with chloroform. Previous investigators have made isolated determinations of glycogen, and others have estimated the amount of fat and glycogen in the liver by histological staining. The latter method is only qualitative, and may be entirely misleading, as comparisons with chemical analysis show (ourselves, unpublished, and others $(7 c, 8 a))$.

The white rat was chosen as the experimental animal, because of the ease of attainment of adequate maintenance and growth on diets predominating in one or the other of the foodstuffs, and also because of the high degree of uniformity attainable in the composition of the liver on a given ration.

A prolonged dietary régime, with chemical analyses of the resultant composition of the liver, has yielded information which, when correlated with the histological evidence, reveals the influence of each of the foodstuffs in modifying the hepatic injury by chloroform. From this evidence 
have been derived certain deductions concerning the mechanism by which a high carbohydrate, fat, or protein dietary affects the susceptibility of the liver to injury by chloroform.

\section{EXPERIMENTAL METHODS}

Male albino rats were purchased at different ages and reared to a weight of 150 to 200 grams on a Steenbock (9) diet modified by substituting two per cent dried brewer's yeast for two per cent corn; this constituted the "stock" diet.

The special diets (Table I), varying in carbohydrate, protein, and fat, were fed for a period of two to four weeks following the "stock" ration. In the groups of animals, designated VII-s in Table II, Diet VII was followed by an exclusive sucrose feeding for seven days. The result of this procedure was an animal whose liver contained both a high fat content as well as a high glycogen content, provided the rats ate sufficient of the sucrose offered. Group 8, Table II, while on Diet VII received, daily for nine days, about $160 \mathrm{mgm}$. of added choline in the form of choline chloride, in part mixed with the food and partially administered in solution, per os, also for the purpose of obtaining a higher concentration of hepatic glycogen and lower fatty-acids than was usually present on this diet. Groups 16 and 17 (Table II) received no food but were permitted water for the period of time designated in the Table. To the rats in Group 17, $100 \mathrm{mgm}$. of choline (as choline chloride) in solution was administered, per os, daily for three days preceding the withdrawal of food, and also during the period of starvation.

The chloroform, for anesthesia, was volatilized in a Gwathmay three chamber volatilizing apparatus connected to a glass manifold leading to five percolator jars, each large enough to hold one rat. Clamps regulated the flow of the chloroform-air mixture led into each chamber. A by-pass, for air alone, led a constant supply of air to each jar. Thus each rat was maintained in a uniform state of anesthesia at a level at which there was complete absence of movement. The depth of anesthesia was best judged by the movements of the tactile hairs (whiskers), the movement of which becomes slower the deeper the anesthesia. The period of anesthesia was uniformly one hour.

Twenty-four hours (except where noted) after the anesthesia with chloroform, about $50 \mathrm{mgm}$. of sodium amytal was administered intraperitoneally. The abdomen was opened and, very rapidly, the caudate lobe of the liver was removed and placed in alcohol, later to be treated with Best's carmine stain; and a portion of the posterior lobule of the right lobe was boiled in a weighed amount of potassium hydroxide and later reweighed for glycogen determination. The remaining lobes were then removed, freed of extraneous tissue, and excess blood allowed to drain out. The left lobe (about 2.5 to 3.3 grams) was used for lipid analyses, the median lobe for solids, and the remainder of the right lobe was fixed in formalin for Sudan IV and hematoxylin and eosin staining. Glycogen was determined by the method of Good, Kramer, and Somogyi (10), using the Shaffer-Hartman reagent Number 2 (11) for the determination of glucose after hydrolysis. Total fatty acids were determined on the alcohol-ether extract of the liver by Long's (12) modification of the Stoddard and Drury method (13). Liver solids were obtained by drying the sample at $100^{\circ}$ C. for 36 hours. Precisely the same histological and chemical procedures were employed with the normal control rats.

The criteria employed in the histological examination of the tissues were as follows. By the term degeneration is meant that, to a varying degree, the hepatic cells have undergone considerable swelling often to several times their normal size. The cytoplasm has a hyaline appearance and does not stain sharply with hematoxylin

TABLE I

Composition of diets

\begin{tabular}{|c|c|c|c|c|c|c|c|c|c|c|}
\hline & \multicolumn{6}{|c|}{ Percentage composition } & \multicolumn{4}{|c|}{ Apportionment of calories } \\
\hline & Diet & Diet & $\begin{array}{l}\text { Diet } \\
\text { III }\end{array}$ & $\begin{array}{l}\text { Diet } \\
\text { VI }\end{array}$ & $\begin{array}{l}\text { Diet } \\
\text { VII }\end{array}$ & $\begin{array}{l}\text { Diet } \\
\text { VIII }\end{array}$ & $\begin{array}{c}\text { Diet } \\
\text { number }\end{array}$ & Protein & $\begin{array}{c}\text { Carbo- } \\
\text { hydrate }\end{array}$ & Fat \\
\hline 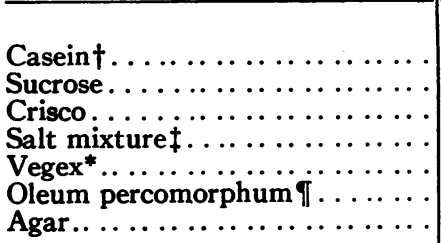 & $\begin{array}{l}16.0 \\
77.5 \\
\\
3.1 \\
3.2 \\
0.19\end{array}$ & $\begin{array}{c}28.2 \\
60.3 \\
5.3 \\
5.9 \\
0.33\end{array}$ & $\begin{array}{c}20.0 \\
48.3 \\
21.8 \\
4.8 \\
4.9 \\
0.24\end{array}$ & $\begin{array}{c}81.2 \\
\\
7.2 \\
4.0 \\
7.4 \\
0.20\end{array}$ & $\begin{array}{r}9.6 \\
42.5 \\
38.7 \\
3.6 \\
5.3 \\
0.29\end{array}$ & $\begin{array}{l}9.0 \\
79.9 \\
2.8 \\
7.2 \\
0.27 \\
0.89\end{array}$ & $\begin{array}{l}\text { I } \\
\text { II } \\
\text { III } \\
\text { VI } \\
\text { VII } \\
\text { VIII }\end{array}$ & $\begin{array}{l}\text { per cent } \\
17 \\
17 \\
17 \\
83.3 \\
6.9 \\
10.1\end{array}$ & $\begin{array}{l}\text { per cent } \\
83 \\
41 \\
30.4 \\
89.9\end{array}$ & $\begin{array}{l}\text { per cent } \\
83 \\
42 \\
16.7 \\
62.7\end{array}$ \\
\hline Calories per 10 grams...$\ldots \ldots$ & 38.3 & 67.6 & 48.3 & 40.0 & 57.4 & 36.5 & & & & \\
\hline
\end{tabular}

* Kindly supplied by the Vitamin Food Company, New York City.

+ Casein Number 453, Casein Manufacturing Company of America, New York City, extracted thoroughly with alcohol and ether.

$\ddagger$ Salt mixture 185, McCollum, E. V. and Simonds, N., J. Biol. Chem., 1917, 32, 191.

T. Kindly supplied by Meạd, Johnson and Company, Evansville, Indiana. 
TABLE II

Diet, composition of liver, and hepatic damage 24 hours after chloroform anesthesia

\begin{tabular}{|c|c|c|c|c|c|c|c|c|c|c|c|}
\hline \multirow[b]{2}{*}{$\begin{array}{c}\text { Group } \\
\text { number }\end{array}$} & \multirow[b]{2}{*}{ Diet } & \multicolumn{3}{|c|}{$\begin{array}{c}\text { Control } \\
\text { Unanesthetized }\end{array}$} & \multicolumn{6}{|c|}{$\begin{array}{l}\text { Experimental } \\
\text { Anesthetized }\end{array}$} & \multirow[b]{2}{*}{ Remarks } \\
\hline & & $\begin{array}{c}\text { Num- } \\
\text { ber of } \\
\text { rats }\end{array}$ & $\begin{array}{c}\text { Average } \\
\text { glyco- } \\
\text { gen }^{*}\end{array}$ & $\begin{array}{c}\text { Average } \\
\text { fatty } \\
\text { acidst }\end{array}$ & $\begin{array}{c}\text { Num- } \\
\text { ber of } \\
\text { rats }\end{array}$ & $\begin{array}{c}\text { Average } \\
\text { glyco- }^{\text {gen }}\end{array}$ & $\begin{array}{c}\text { Average } \\
\text { fatty } \\
\text { acidst }\end{array}$ & $\begin{array}{l}\text { Number } \\
\text { showing } \\
\text { degener- } \\
\text { ation }\end{array}$ & $\begin{array}{c}\text { Number } \\
\text { with } \\
\text { necrosis. }\end{array}$ & $\begin{array}{l}\text { Total } \\
\text { dam- } \\
\text { aged }\end{array}$ & \\
\hline $\begin{array}{r}1 \\
2 \\
3 \\
4 \\
5 \\
6 \\
7 \\
8 \\
9 \\
10 \\
11 \\
12 \\
13\end{array}$ & $\begin{array}{l}\text { Stock } \\
\text { I } \\
\text { VI } \\
\text { III } \\
\text { II } \\
\text { II } \\
\text { VIII } \\
\text { VII-c } \\
\text { II } \\
\text { VII-s } \\
\text { II } \\
\text { VII } \\
\text { VII-s }\end{array}$ & $\begin{array}{r}19 \\
14 \\
5 \\
9 \\
4 \\
2 \\
2 \\
3 \\
3 \\
4 \\
4 \\
8 \\
3\end{array}$ & $\begin{array}{c}\text { per cent } \\
5.6 \\
5.5 \\
2.4 \\
5.5 \\
1.2 \\
1.5 \\
7.0 \\
5.0 \\
1.4 \\
8.3 \\
3.1 \\
5.4 \\
0.9\end{array}$ & $\begin{array}{c}\text { per cent } \\
8.6 \\
9.1 \\
11.4 \\
13.2 \\
17.0 \\
20.7 \\
21.7 \\
23.4 \\
24.3 \\
24.5 \\
26.9 \\
38.4 \\
53.6\end{array}$ & $\begin{array}{r}42 \\
22 \\
10 \\
22 \\
8 \\
8 \\
2 \\
7 \\
6 \\
8 \\
8 \\
10 \\
6 \\
7\end{array}$ & $\begin{array}{c}\text { per cent } \\
2.5 \\
1.8 \\
1.9 \\
2.1 \\
0.4 \\
0.9 \\
0.3 \\
1.4 \\
1.2 \\
1.0 \\
1.6 \\
0.2 \\
0.4\end{array}$ & $\begin{array}{c}\text { per cent } \\
12.1 \\
11.0 \\
16.3 \\
14.1 \\
13.7 \\
24.1 \\
39.0 \\
29.9 \\
21.3 \\
24.2 \\
22.4 \\
39.0 \\
49.3\end{array}$ & $\begin{array}{l}2 \\
2 \\
3 \\
4 \\
3 \\
4 \\
0 \\
1 \\
3 \\
0 \\
4 \\
0 \\
0\end{array}$ & $\begin{array}{l}2 \\
0 \\
0 \\
4 \\
2 \\
3 \\
2 \\
5 \\
3 \\
8 \\
5 \\
6 \\
7\end{array}$ & $\begin{array}{c}\text { per cent } \\
10 \\
9 \\
30 \\
36 \\
63 \\
88 \\
100 \\
86 \\
100 \\
100 \\
90 \\
100 \\
100\end{array}$ & $\begin{array}{l}\text { Killed } 48 \text { hours } \\
\text { Given choline chloride per os } \\
\text { Fed only sucrose } 7 \text { days } \\
\text { Fed only sucrose } 7 \text { days. }\end{array}$ \\
\hline $\begin{array}{l}14 \\
15 \\
16\end{array}$ & $\begin{array}{l}\text { VII } \\
\text { VII-s } \\
\text { No food } \\
\text { for } 24 \\
\text { hours } \\
\text { No food } \\
\text { for } 48 \\
\text { hours }\end{array}$ & $\begin{array}{l}4 \\
4 \\
4\end{array}$ & $\begin{array}{l}2.7 \\
3.5 \\
0.12 \\
\\
\\
0.59\end{array}$ & $\begin{array}{l}56.9 \\
62.4 \\
14.5 \\
\\
15.0\end{array}$ & $\begin{array}{r}13 \\
6 \\
10\end{array}$ & $\begin{array}{l}0.4 \\
1.7 \\
0.49\end{array}$ & $\begin{array}{l}59.8 \\
70.4 \\
16.8\end{array}$ & $\begin{array}{l}1 \\
0 \\
0\end{array}$ & $\begin{array}{r}12 \\
6 \\
10\end{array}$ & $\begin{array}{l}100 \\
100 \\
100\end{array}$ & $\begin{array}{l}\text { Fed only sucrose } 7 \text { days } \\
\text { Stock diet before starvation. } \\
\text { No food } 24 \text { hours after } \\
\text { anesthesia }\end{array}$ \\
\hline 17 & $\begin{array}{r}\text { No food } \\
\text { for } 24 \\
\text { hours } \\
\text { No food } \\
\text { for } 48 \\
\text { hours }\end{array}$ & 4 & $\begin{array}{l}0.10 \\
0.45\end{array}$ & $\begin{array}{l}13.8 \\
12.6\end{array}$ & 10 & 0.21 & 14.1 & 1 & 8 & 90 & $\begin{array}{l}\text { Choline for } 3 \text { days previous } \\
\text { and during starvation }\end{array}$ \\
\hline
\end{tabular}

* Glycogen is expressed as percentage of the wet weight of the liver.

$\dagger$ Fatty acids are expressed as percentage of the dry weight of the liver.

and eosin. The cell outlines are, in the main, discrete, but they are, at times, broken, so that the boundaries between the cells may not be sharply defined. The nuclei are often pyknotic. The appearance is that which one would expect if groups of cells had become markedly edematous, in the midst of others which appeared to be normal.

Where necrosis is reported the nuclei are greatly distorted or destroyed. The cell outlines have disappeared and the necrotic zone is in a state of complete disorganization. Obviously necrosis and degeneration frequently exist together. In many instances the necrosis is so extensive that the degree of associated degeneration can not be estimated with any degree of accuracy.

In the sections from livers in which fat has completely infiltrated the liver cells, it is at times difficult to state the exact extent of the necrosis. If no normal liver cells are present, and the cells between massive areas of fatty infiltration are necrotic, it is assumed that extensive necrosis is present. This is especially the case where the outlines of the fatty infiltrated cells are in part destroyed and the nuclei, which are pushed to the side by the fat droplets, have undergone extensive change or been destroyed.

The histological abnormalities are reported as degeneration, when this alone was found; as necrosis, even though degeneration was also present. No attempt is made to indicate the extent of the particular degree of damage.

\section{EXPERIMENTAL}

By altering the diet (Table I) groups of rats were obtained whose hepatic lipid varied over a wide range (from 8.6 to 62.4 per cent of fatty acids by dry weight), and in which the glycogen of the liver was high, or low, at any given level of lipid concentration. At comparable fat levels the glycogen concentrations in the livers varied by 200 to 600 per cent. The protein content of the rations varied considerably, above and below that usually offered to growing rats. Furthermore, the dietaries have been, so far as is possible, de- 
vised so that data can be compiled (Table II), from which the rôle of each of the foodstuffs, and its resulting liver constituent, can be evaluated without being pertinently affected by the others.

In Table II the various groups of rats which had received the diets in Table I have been arranged in an ascending order of the average percentage content of fatty acids in their livers. In Table III (Compilation 1) the data have been apportioned into three groups in which the initial average concentration of fatty acid was low (10.5 per cent), at a medium level for our series (24.1 per cent) and high (49.7 per cent). It will be noted that the average initial concentration of glycogen in the livers of these groups did not differ greatly, namely, 4.9, 4.5, and 3.7 per cent respectively. The percentage of rats whose livers showed damage was 21 per cent in the low fat groups, 92 per cent at the medium, and 100 per cent at the very high level; livers the cells of which exhibited only degenerative changes are included, as well as those showing necrosis. The incidence of necrosis in the three groups was 8 per cent, 63 per cent, and 97 per cent. The incidence and the severity of the damage to the hepatic cells twentyfour hours following one hour of chloroform anesthesia increased progressively with an increase in the concentration of fatty acids in the liver. This is also apparent in the compilation of the individual groups of rats in Table II.

A further analysis of the data consisted of a division into groups with an initially high and low concentration of hepatic glycogen, in an effort to reveal the possible effect of this constituent of the liver in affecting its susceptibility to injury by chloroform. The grouping is somewhat arbitrary, but, we believe, fair. A concentration of glycogen of 5.0 per cent or above has been considered high and concentrations less than 5.0 per cent as low. In our experience in the rat, an average of 5.5 per cent of hepatic glycogen results from balanced diets high in carbohydrate, as illustrated by our "stock" ration and Diet I.

The first analysis (Table III, Compilation 2) of the results, on this basis, includes all of the data in Table II. The average initial concentrations of glycogen are 5.7 per cent for the high groups, and 2.2 per cent for the low. Anesthetization with chloroform in the former group (109 rats) was followed by degeneration or necrosis of the liver in 33 per cent of the rats. In the second group (68 rats) with lower hepatic glycogen, 82 per cent showed hepatic injury. Of the total percentage exhibiting hepatic cellular damage, necrosis was found in 25 per cent of the livers with high initial (before anesthesia) glycogen and 56 per cent with the low. Conclusions from these results are invalidated by the fact that the average fatty acid concentration in the group high in glycogen was 15.7 per cent, whereas it was 34.0 per cent at the lower level of glycogen. Since the previous analysis of the data showed an increase in liver injury with increased lipid concentration, it became necessary to select from the data groupings in which the initial average fatty acid concentration was about the same. This was accomplished by eliminating the groups with very high and low concentrations of hepatic fatty acids before anesthesia, thus restricting the range between 11 and 27 per cent. Two groups are thus obtained, one with a hepatic glycogen of 6.2 per cent and with 18.4 per cent of fatty acids, and another with an average of 2.0 per cent glycogen and 19.3 per cent of fatty acids. In this arrangement of the data, the 39 rats high in glycogen showed a total incidence of hepatic injury of 62 per cent (13 per cent degeneration and 49 per cent necrosis), and at the lower level of glycogen (42 rats) 71 per cent of the livers presented histological evidence of cellular abnormalities (40 per cent degeneration and 31 per' cent necrosis). These figures fail to show that a high concentration of hepatic glycogen, per se, confers a protection against the hepatoxic action of chloroform in rats with the same medium concentration of fatty acids. In fact the severity of the lesions in the high glycogen group is slightly greater than in the low.

In evaluating the adverse effect of a high hepatic lipid content and the advantage, if any, of a high glycogen content the data as a whole have been arranged graphically. In Figure 1 the percentage incidence of liver damage in all of the rats in Table II has been plotted along the abscissa, and both the hepatic fatty acid concentration and the glycogen as ordinates. The fatty acid concentrations group themselves very closely along a straight line which slopes upward with the increase in the percentage of injured livers. This indicates a progressive additional incidence of 
TABLE III

Compilation of data from Table II

\begin{tabular}{|c|c|c|c|c|c|c|c|c|c|c|}
\hline \multirow{2}{*}{ Group numbers } & \multirow{2}{*}{$\begin{array}{l}\text { Experimental } \\
\text { state }\end{array}$} & \multicolumn{3}{|c|}{ Control } & \multicolumn{6}{|c|}{$\begin{array}{l}\text { Experimental } \\
\text { Apportionment of liver damage }\end{array}$} \\
\hline & & $\begin{array}{l}\text { Number } \\
\text { of } \\
\text { rats }\end{array}$ & $\begin{array}{l}\text { Average } \\
\text { liver } \\
\text { glycogen }\end{array}$ & $\begin{array}{c}\text { Average } \\
\text { liver fatty } \\
\text { acids }\end{array}$ & $\begin{array}{c}\text { Number } \\
\text { of } \\
\text { rats }\end{array}$ & Dege & ation & & osis & $\begin{array}{l}\text { Total } \\
\text { damaged }\end{array}$ \\
\hline & & & per cent & per cent & & number & per cent & number & per cent & per cent \\
\hline
\end{tabular}

COMPILATION 1. LIVER DAMAGE AT ASCENDING FAT LEVELS

\begin{tabular}{l|l|l|l|l|r|r|r|r|r|r|r}
\hline 1 to 5 (inc.)..... & Low fat & 51 & 4.9 & 10.5 & 104 & 14 & 13 & 8 & 8 & 21 \\
6 to 11 (inc.).... & Medium fat & 18 & 4.5 & 24.1 & 41 & 12 & 29 & 26 & 63 & 92 \\
12 to 15 (inc.).. & High fat & 19 & 3.7 & 49.7 & 32 & 1 & 3 & 31 & 97 & 100 \\
\hline
\end{tabular}

COMPILATION 2. LIVER DAMAGE AT HIGH AND LOW GLYCOGEN LEVELS

\begin{tabular}{|c|c|c|c|c|c|c|c|c|c|c|}
\hline $\begin{array}{r}1,2,4,7,8,10 \\
12 \ldots \ldots \ldots \ldots \ldots \\
3,5,6,9,11,13 \\
14,15 \ldots \ldots \ldots\end{array}$ & $\begin{array}{l}\text { High } \\
\text { glycogen } \\
\text { Low glycogen }\end{array}$ & $\begin{array}{l}59 \\
29\end{array}$ & $\begin{array}{l}5.7 \\
2.2\end{array}$ & $\begin{array}{l}15.7 \\
34.0\end{array}$ & $\begin{array}{r}109 \\
68\end{array}$ & $\begin{array}{r}9 \\
18\end{array}$ & $\begin{array}{r}8 \\
26\end{array}$ & $\begin{array}{l}27 \\
38\end{array}$ & $\begin{array}{l}25 \\
56\end{array}$ & $\begin{array}{l}33 \\
82\end{array}$ \\
\hline $\begin{array}{l}4,7,8,10 \ldots \ldots \\
3,5,6,9,11 \ldots\end{array}$ & $\begin{array}{l}\text { High } \\
\text { glycogen } \\
\text { Low glycogen }\end{array}$ & $\begin{array}{l}18 \\
18\end{array}$ & $\begin{array}{l}6.2 \\
2.0\end{array}$ & $\begin{array}{l}18.4 \\
19.3\end{array}$ & $\begin{array}{l}39 \\
42\end{array}$ & $\begin{array}{r}5 \\
17\end{array}$ & $\begin{array}{l}13 \\
40\end{array}$ & $\begin{array}{l}19 \\
13\end{array}$ & $\begin{array}{l}49 \\
31\end{array}$ & $\begin{array}{l}62 \\
71\end{array}$ \\
\hline
\end{tabular}

COMPILATION 3. LIVER DAMAgE ON HIGH AND LOW PROTEIN DIETS

\begin{tabular}{|c|c|c|c|c|c|c|c|c|c|c|}
\hline $\begin{array}{r}1,2,3,4,5,6,9 \\
11 \ldots \ldots \ldots \ldots \\
7,8,10,12,13 \\
14,15 \ldots \ldots \ldots\end{array}$ & $\begin{array}{l}\text { High protein } \\
\text { diet } \\
\text { Low protein } \\
\text { diet }\end{array}$ & $\begin{array}{l}60 \\
28\end{array}$ & $\begin{array}{l}4.5 \\
4.7\end{array}$ & $\begin{array}{l}12.6 \\
41.3\end{array}$ & $\begin{array}{r}128 \\
49\end{array}$ & 25 & $\begin{array}{r}19 \\
4\end{array}$ & $\begin{array}{l}19 \\
46\end{array}$ & $\begin{array}{l}15 \\
94\end{array}$ & $\begin{array}{l}34 \\
98\end{array}$ \\
\hline $\begin{array}{l}5,6,9,11 \ldots \ldots \\
7,8,10 \ldots \ldots\end{array}$ & $\begin{array}{l}\text { High protein } \\
\text { diet } \\
\text { Low protein } \\
\text { diet }\end{array}$ & $\begin{array}{r}13 \\
9\end{array}$ & $\begin{array}{l}1.9 \\
6.9\end{array}$ & $\begin{array}{l}22.3 \\
23.5\end{array}$ & $\begin{array}{l}32 \\
17\end{array}$ & $\begin{array}{r}14 \\
1\end{array}$ & $\begin{array}{r}43 \\
6\end{array}$ & $\begin{array}{l}13 \\
15\end{array}$ & $\begin{array}{l}41 \\
88\end{array}$ & $\begin{array}{l}84 \\
94\end{array}$ \\
\hline
\end{tabular}

COMPILATION 4. LIVER DAMAGE AT ASCENDING FAT LEVELS. HIGH PROTEIN DIETS

\begin{tabular}{l|l|l|l|l|l|l|l|r|r|r|r}
\hline 1 to 2 (inc.)..... & Low fat & 33 & 5.6 & 8.8 & 64 & 4 & 6 & 2 & 3 & 9 \\
3 to 5 (inc.)..... & Medium fat & 18 & 3.7 & 13.5 & 40 & 10 & 25 & 6 & 15 & 40 \\
$6,9,11 \ldots . .$. & High fat & 9 & 2.2 & 24.7 & 24 & 11 & 46 & 11 & 46 & 92 \\
\hline
\end{tabular}

COMPILATION 5. LIVER DAMAGE AT HIGH AND LOW GLYCOGEN LEVELS. HIGH PROTEIN DIETS

\begin{tabular}{l|l|l|l|l|l|l|l|l|l|l|l|l}
\hline $4 . \ldots \ldots \ldots \ldots$ & $\begin{array}{l}\text { High } \\
\text { glycogen }\end{array}$ & 9 & 5.5 & 13.2 & 22 & 4 & 18 & 4 & 18 & 36 \\
$3,5 \ldots \ldots \ldots$ & Low glycogen & 9 & 1.9 & 13.9 & 18 & 6 & 33 & 2 & 11 & 44 \\
\hline
\end{tabular}

COMPILATION 6. LIVER DAMAGE DURING STARVATION

\begin{tabular}{|c|c|c|c|c|c|c|c|c|c|c|}
\hline $\begin{array}{l}16,17 \ldots \ldots \ldots \ldots \\
4,5 \ldots \ldots \ldots \ldots\end{array}$ & $\begin{array}{l}\text { No food } \\
\text { II; III }\end{array}$ & $\begin{array}{r}8 \\
13\end{array}$ & $\begin{array}{l}0.1 \\
4.2\end{array}$ & $\begin{array}{l}14.2 \\
14.4\end{array}$ & $\begin{array}{l}20 \\
30\end{array}$ & $\begin{array}{l}1 \\
7\end{array}$ & $\begin{array}{r}5 \\
23\end{array}$ & $\begin{array}{r}18 \\
6\end{array}$ & $\begin{array}{l}90 \\
20\end{array}$ & $\begin{array}{l}95 \\
43\end{array}$ \\
\hline
\end{tabular}




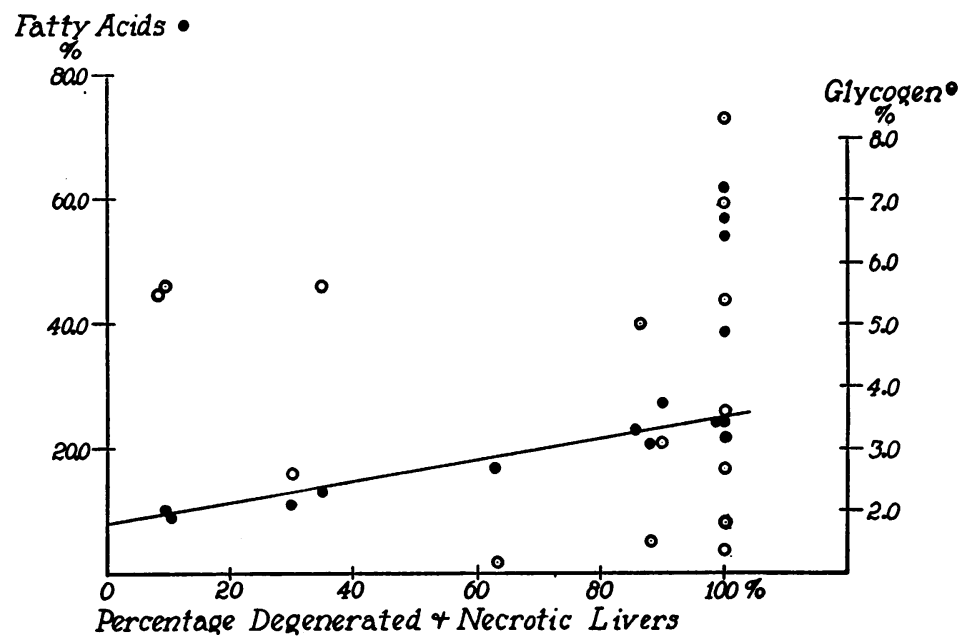

Fig. 1. Chloroform Injury to Liver in Relation to Liver Lipid AND GLYCOGEN

damage to the liver as the hepatic lipid is increased. No similar relationship exists between the hepatic glycogen and the incidence of hepatic damage. The glycogen, therefore, exerted no apparent influence upon the susceptibility of the liver to the toxic effects of the chloroform. When the fatty-acid content reaches about 25 per cent all of the livers exhibit, to some degree, histological evidence of damage.

The various groups of rats are next apportioned (Table III, Compilation 3) into those with relatively high and low content of protein in their rations. Diets which derived 17 per cent or more of their total calorific value from protein were considered to be high in that foodstuff. This included the "stock" ration and Diets I, II, III, and VI. Seventeen per cent of the calories from protein is ample for the requirements of young growing rats. The diets low in protein contained but 10 per cent or less (Diets VII and VIII) of their calories as protein. This is distinctly less than is necessary to maintain good growth in the young rat. On this basis the data in Table II have been analyzed to determine the effect of the protein content of the food upon the resistance of the liver to the effects of chloroform.

Two analyses of the data have been made. The first includes all of the rats in Table II. The hepatic fatty acid concentrations, in the two groups so obtained, differ so greatly (12.6 and 41.3 per cent) that no conclusions as to the action of the protein would be justifiable. It was necessary, therefore, to select groups of rats with comparable concentrations of hepatic lipid. This was accomplished by utilizing only those groups of rats with hepatic fatty acid concentrations ranging between 17 and 27 per cent. The average initial fatty acid concentration in the control rats, which received no chloroform, was 22.3 per cent in the animals which received a high protein diet, and 23.5 per cent in those whose rations were low in calories from protein. Of the 32 rats on the higher protein intake, the livers of 84 per cent were histologically abnormal following chloroform anesthesia. Hepatic cellular injury occurred in 94 per cent of the 17 rats on the diet low in protein. This difference is of doubtful significance. The marked and significant difference is to be found in the severity of the cellular changes. In the high protein group, areas of hepatic cellular necrosis were found in but 41 per cent of the rats; while in those which received a ration low in protein, necrosis was present in 88 per cent of the livers. It would appear that, although a high protein diet may not markedly affect the total incidence of hepatic damage due to chloroform, it does decidedly reduce the degree of the injury. This protective action of a diet high in protein reveals itself in animals whose livers contained a rather high lipid content (22 per cent). The average hepatic glycogen concentration in the animals on the higher protein intake was 1.9 per cent, 
and 6.9 per cent on the lower. Therefore, the low protein animals had whatever advantage may accrue from a high hepatic glycogen content. Nevertheless, the high content of hepatic glycogen failed to exert a beneficial action of sufficient degree to become apparent in the presence of the detrimental effect of the low intake of protein and the same high hepatic lipid.

The slightly lesser percentage of necrosis in the rats with low hepatic glycogen (2.0 per cent) in the second grouping of Compilation 2 (Groups 3, $5,6,9$, and 11 ) is probably due to the fact that the rations of these rats were all high in protein calories.

Inasmuch as the data show that dietary protein exerts a protective action against the toxic effects of chloroform upon the liver, it becomes necessary to re-examine the data bearing upon the action of a high hepatic lipid or glycogen content, in the analysis of which this factor was not taken into account. The smooth slope of the line which passes through the fatty acid concentrations in Figure 1 would indicate that other factors influenced the susceptibility of the liver to injury to a lesser degree than did the hepatic lipid.

Additional evidence will be presented in which the factor of the protein is controlled. In Compilation 4 of Table III, all of the data were derived from dietaries in which the protein was high. It comprised 17 per cent of the total calorific value of each unit amount of the ration, except in one group of rats (Number 3, Diet VI, Table II) in which it was 83 per cent. In substantiation of the previous analysis of the data, the incidence and severity of liver damage increased with an increase in the hepatic fatty acid concentration. Although the hepatic glycogen concentrations are not the same in this compilation, none are very low, and no evidence in these experiments indicates that this factor is of importance.

The influence of the hepatic glycogen content is also again analyzed in groups of rats which were fed rations comparable with respect to protein (Compilation 5, Table III). The total incidence of histological abnormality was 36 per cent in the rats with high glycogen (5.5 per cent) and 44 per cent in the low ( 1.9 per cent). Necrosis was found in 18 per cent of the livers with the high glycogen content and 11 per cent in those with the low. These differences are of no significance. The average initial hepatic fatty acid concentration, namely 13 to 14 per cent, is considerably less than in the previous compilation (Number 2), consequently the damage from the chloroform was not so great. Therefore, any protective action of the hepatic glycogen should have a better opportunity to reveal itself. Despite this fact, and with the same high level of protein in the food, the glycogen content of the liver failed to show any protective action.

The effect of withdrawal of all food, except water, for twenty-four hours preceding the administration of the chloroform was determined. This length of time without food has a profound effect in depleting the hepatic glycogen of the rat. In the two groups of control animals (Numbers 16 and 17, Table II) it was reduced to about 0.1 per cent. The anesthetized rats were offered no food during the twenty-four hours following the anesthesia, when they were sacrificed. Hence, the final concentrations of hepatic glycogen and fatty acids are to be compared with those in the control animals starved for forty-eight hours. To one group of rats (Number 17) choline chloride was administered in an attempt to prevent the increase in hepatic lipid which attends starvation. Since this procedure was not successful, the two groups are analyzed together (Compilation 6, Table III).

The incidence of hepatic cellular injury in the starved rats is compared with that which was found in fed animals with the same initial hepatic fatty acid concentration, but inevitably much higher glycogen levels (Groups 4 and 5, Table II). Ninety-five per cent of the livers of the starved groups (20 rats) were histologically abnormal; in 90 per cent, areas of cellular necrosis were found. The fed group ( 30 rats) showed but 43 per cent of damaged livers, with 20 per cent necrotic. The livers of the starved rats, therefore, were more susceptible to the effects of chloroform than those of the fed animal with the same low concentration (14 per cent) of hepatic fatty acids. The extent and severity of the damage to the liver of the starved rat is almost maximal and nearly equivalent to that in a fed animal with the highest (49.7 per cent) concentration of hepatic lipid. 


\section{DISCUSSION}

Regardless of the reasons for the toxic action of chloroform upon the cells of the liver, the evidence presented shows that the incidence and degree of the injury increases with the concentration of lipid in the liver. A high fat intake increases the amount of fat deposited in the liver. Hence a causal relationship is established between our results and the previous finding, that a high fat diet increases the susceptibility of the liver to injury by chloroform $(3,4,5)$, and, according to Davis (14), also by carbon tetrachloride. The data which are presented here serve as a firmer basis for the following proposed explanation of the mechanism of this phenomenon.

A rational explanation of the greatly increased susceptibility of a fatty liver to damage by chloroform was suggested by Wells in 1908 (8b, 8c). The fact that, clinically, chloroform seemed particularly to affect fatty livers (15), added to the well known solubility of chloroform in fats, led Wells to state: "It would seem probable therefore, that a fatty liver would abstract much more chloroform from the blood than a normal liver and that the chloroform would thus act more strongly and for a longer time on the protoplasm of the fatty liver cells than it would in a normal liver." Opie and Alford ( $3 \mathrm{~b}$ ) accepted this explanation as probable, and pointed out that necrosis by chloroform occurred around the central vein in the lobule of the liver, where fat is deposited most abundantly.

The following clarification of the Well's hypothesis is suggested. The fat within the cells of the liver acts as a reservoir for the chloroform; therefore, a concentration sufficient to produce injury will be maintained during a prolonged period of desaturation. Final proof of this hypothesis will rest upon the chemical determination, following anesthesia, of the relative amounts of chloroform in livers with different contents of lipid. On " a priori" grounds the high distribution coefficient of chloroform between fat and water would make it quite certain that adequate chemical methods would reveal concentrations of chloroform corresponding to the amount of lipid in the hepatic cells.

The data reveal no evidence that the level of the hepatic glycogen, per se, at the time of anes- thesia, influences the toxic action of chloroform. No plausible theory has been advanced to explain the protection conferred upon the liver by a high carbohydrate diet. The hypotheses which have been advanced to explain this protection all imply that it is due to the abundant and ready supply of energy made available by the increased deposits of hepatic glycogen which result from the diet.

The work and concepts of Rosenfeld (7) led to the suggestion that the administration of glucose might be of value in the prevention and treatment of necrosis of the liver by chloroform used for anesthesia (16).

$\mathrm{He}(7 \mathrm{a}, 7 \mathrm{~d})$ found that, in a variety of physiological and abnormal conditions, including poisoning by chloroform, in which the hepatic glycogen stores are nearly exhausted, there results an infiltration of fat into the liver. This occurs, according to Rosenfeld, because in the absence of glycogen, lipid, transported from the fat depots to the liver, accumulates there, since it cannot be burned unless carbohydrate is available and oxidized simultaneously. From these and other concepts, Rosenfeld ( $7 \mathrm{~b}$ ) concluded that, if the animal receives carbohydrate, the energy needs of the liver, increased as a defense against a noxious substance such as chloroform, will be satisfied; the liver will be protected, and hepatic fattyinfiltration prevented. Rosenfeld (7d) stated that the detoxifying power ("entgiftenden Fähigheiten") of the liver is the greater the richer its content of carbohydrate.

Opie and Alford ( $3 \mathrm{~b}$ ) suggested that the necrosis produced by chloroform, phosphorus, and similar substances is perhaps the anatomical expression of advanced disintegration of body protein. Hence, carbohydrate may be of value in limiting the necrosis due to chloroform by exerting its recognized function of sparing body protein.

The implicit assumption in all previous concepts is that the depletion of hepatic glycogen by chloroform is due to an increased combustion, inferentially in the liver. An increased glycogenolysis does occur in the liver of both the dog (2) and the rat following anesthesia with chloroform, with the result that the stores of hepatic glycogen are reduced or almost depleted; an hyperglycemia is an invariable accompaniment. The behavior of 
the blood sugar, in relation to the glycogen stores in the liver, does not suggest that utilization of glucose is proceeding at a greatly heightened rate; the sugar in the blood may be above its preanesthetic level for twenty-four hours, even though the hepatic glycogen is almost depleted at the end of this period of time (2). This would seem to be best explained by an inability of the hepatic cells to retain glycogen, rather than by the needs of a heightened metabolic activity of the hepatic cells as suggested by Rosenfeld ( $7 \mathrm{~b})$. The existence of a deranged capacity of the liver to deal with carbohydrate is supported by the finding (2) that glucose administered by stomach tube, twenty-four hours following the anesthesia, results in less deposition of hepatic glycogen than in the normal dog.

The same type of reasoning may be applied to the accumulation of lipid in the liver as a consequence of chloroform inhalation, insofar as it is dependent upon carbohydrate utilization by the liver. In the dog it has been found that fat begins to accumulate in the liver at the end of a one or two-hour period of anesthesia with chloroform, at a time when considerable glycogen is still present in the liver (2). Therefore, the early fatty infiltration, during and immediately following the anesthesia, cannot be explained solely on the basis of a deficiency of carbohydrate to burn it, as claimed by Rosenfeld (7d, 7e), if the glucose available in the hepatic glycogen is capable of combustion. For the same reason, the initiation of the transport of lipid to the liver by the blood from the fat depots, in this early period, cannot be due entirely to a depletion of hepatic glycogen. Analysis of the data in this paper shows no greater infiltration of lipid into the liver of the rats with initially low than in those with high hepatic glycogen.

The hypotheses which assume that glycogen, per se, is effective in protecting the liver against the action of chloroform, receive no support either in these considerations of the behavior of the hepatic glycogen and lipid, and blood sugar, or in the data on the incidence and severity of damage to the liver with high or low content of glycogen.

It would seem that the explanation of the protective action of a high carbohydrate diet must lie in some concomitant effects produced by large deposits of hepatic glycogen. As already stated,
Rosenfeld (7a, 7b) found that, under many conditions in the body, depletion of hepatic glycogen is followed by an increase in fat in that organ and vice versa. Evidence already presented (2), and instances, in this paper, of a coexistence in the liver of a high concentration of glycogen with a high lipid content (Table II, Groups 7, 8, 10, and 12), and other data to be published later, show that the reciprocal relationship of Rosenfield (7d) is not an invariable rule. However, we have found in both the dog and the rat, that a diet rich in carbohydrate, and, in the rat at least, adequate in protein, produces livers which contain maximal concentrations of glycogen, but minimal concentrations of fatty acids. The "stock" diet and Diet 1, Table I, are examples of such dietaries; the concentration of hepatic glycogen and lipid, of normal rats fed with these rations, is shown in Table II. Our experience has shown that, in the normal dog or rat, a high carbohydrate intake, in an otherwise balanced dietary, will cause the hepatic lipid, if high, gradually to diminish in amount.

The susceptibility of the liver to injury by chloroform is markedly enhanced by the presence of small increments of fat (Compilation 4, Table II), hence it would seem plausible to conclude, since glycogen as such is ineffective even at low levels of hepatic lipid (Compilation 5, Table II), that the protective action of a high carbohydrate diet is chiefly due to its effect in reducing hepatic lipid. This hypothesis would satisfactorily account for the reported failure to obtain protection from injury by chloroform when glucose is administered during the anesthesia (4).

Comparisons of the relative protection offered by a carbohydrate and a high protein diet are futile unless the fat contents of the livers are known. In the final analysis, the comparative protective values to the liver of the foodstuffs against chloroform resolves itself into the positive action of dietary protein versus the increased susceptibility due to hepatic lipid.

In view of the high degree of protection which an abundant protein dietary confers upon the liver, it must be conceded that carbohydrate may also be of value under conditions in which it can act as a sparer of protein.

In contrast to this indirect action of carbohydrate in decreasing the damaging effects of chloro- 
form upon the hepatic cells, the protection afforded by protein would appear to be more direct and related to some intrinsic value of the protein itself. Pertinent, in this respect, is the finding (Compilation 3, Table II) that a previous high protein diet protects the liver against necrosis by chloroform at a high level of hepatic fatty acids (22 per cent). This would indicate that the protein factor, whatever it may be, is a very potent one, for it can counteract, to some extent, the untoward effects of a high hepatic lipid, which means that it is effective under conditions in which a very severe injury by chloroform usually occurs.

Moise and Smith (5a) also found that the extent of the necrosis is less in rats on a high protein than on other diets. It may be significant that in the present experiments, as well as in those of Moise and Smith, casein constituted the protein which was fed. Davis and Whipple (4) also reported that, in the dog, skim milk or casein are very protective, while skeletal and cardiac muscle are less so. Opie and Alford (3b) found a greater toxicity of chloroform in rats fed solely meat than in those given a high carbohydrate diet, and concluded that protein is less protective than carbohydrate.

Although the protein action is probably a direct one, certain facts at hand, soon to be published, show that the level of hepatic lipid and glycogen are markedly affected by the amount of protein in the diet. Best, Channon, and their coworkers (17) have reported, and we have confirmation of their finding, that a high protein dietary is conducive to a lesser deposition of liver lipid (i.e., Diet VI, Table II), than is a low protein intake (i.e., Diet VIII, Table II). Here, then, as in the case of a high carbohydrate diet, the level of protein in the dietary may affect the stores of hepatic lipid. It is also apparent from the results obtained from feeding Diet VIII (Table II) that a low protein intake may lead to an increase of lipid in the liver, despite the presence of an excess of carbohydrate calories. This factor is not involved in the discussion in this paper for the comparisons of the high and low protein diets are for rats with about the same concentration of hepatic fatty acids.

The mechanism by which the protein of the diet aids the liver in resisting the necrotic action of chloroform, with our present information, can only be a subject of conjecture, although this problem is being pursued at present in our laboratories.

The question of protein storage in the body, on a high protein diet, becomes of particular importance in relation to the protection conferred by such a diet, especially if we assume that it is due to protein, per se. It is of interest that investigators in the field of protein storage have invariably directed their efforts to the liver as the most probable storehouse for protein. Recently the problem has been investigated by Luck (18). $\mathrm{He}$ found that in the rat, on a high protein intake, in accordance with previous results, the total protein content of the liver, as well as the amount per unit of weight is increased above that found on a low protein diet. Addis, Poo, and Lew (19) in a study of the loss of protein from various organs and tissues of the body during a fast found that the liver loses so much more of its original protein content than any other organ, that it "suggests that it may be a depot for stored protein and that this special sort of protein may be used during fasting in much the same manner as glycogen is used during a fast."

It would seem that there is some basis for believing that a high protein diet previous to liver injury by chloroform may make available stores of protein within the body. This protein, stored or elaborated into hepatic or other body tissue, may serve to protect the cells or to replenish a structure which is being attacked. Which of these alternative mechanisms is operative is impossible to decide at present. It may, however, be supposed that either the available stores of protein prevent or ameliorate the destructive action of the chloroform or that the damage which occurs is rapidly repaired and does not proceed to necrosis. It will be recalled that the data show that the main result of a high, as compared to a low, protein diet is to decrease the incidence of hepatic necrosis. The two processes of damage and repair might be conceived as proceeding at the same time.

The greatly increased susceptibility of the liver of the starved rat to necrosis by chloroform, evident in the data we have presented, is in accord with the previous findings of Davis and Whipple (4) and of Smith and Moise (5b). Since the incidence and degree of the hepatic damage caused 
by chloroform is much greater in the rat which has received no food for twenty-four hours than that in the fed animal with the same low concentration (14 per cent) of hepatic fatty acids, the greater susceptibility of the former animal to hepatic injury is probably not due to differences in the lipid content of the liver. The evidence already presented in this paper makes it very doubtful that the low hepatic glycogen, per se, of the starved animal is the factor responsible for the greater vulnerability of the liver.

In view of these deductions and the importance of the protein factor, it would seem that the most probable deficiency in the unfed animal, responsible for the increased susceptibility to injury, is its stores, of protein, which have been shown to be diminished in the body tissues and especially in the liver when the rat is starved (19). This conclusion is in harmony with our finding of increased hepatic cellular damage in rats on low protein diets as compared to those which received a high protein ration.

The constituents of a balanced diet which, by altering its composition, confer protection upon the liver are the protein, probably directly, and the carbohydrate, indirectly, by conditioning the content of hepatic lipid. The starved animal enjoys to only a slight extent, or not at all, the advantages to be derived from either of these dietary factors. It would follow that if carbohydrate alone were fed, it may be protective to the liver, by virtue of its indirect action as a sparer of protein. This result would depend upon the length of time the carbohydrate is fed, for, as previously stated, the absence of protein intake predisposes to fat deposition in the liver, which might offset the advantage derived from a small amount of conserved protein.

The work of Davis, Hall, and Whipple (20) and Daft, Robscheit-Robbins, and Whipple (21) is of interest in this discussion. They produce evidence from which they conclude that in a starved dog the "protein split products," which usually appear in the urine in increased amounts following chloroform anesthesia, may be partially "conserved" by the administration of glucose, and are thus made available for regeneration, since they find, under these conditions, a more rapid regeneration of the liver cells than in a starved dog not given glucose. They make a sharp dis- tinction between this type of protein sparing action of carbohydrate namely, a " conservation of protein split products," and the usual concept that carbohydrate, instead of protein, is utilized for energy production, when glucose is given to a starved animal, and thus spares the protein "at its source." These findings constitute an excellent example of the protein sparing action of carbohydrate under conditions in which the protein is needed for building of new body tissue. Regardless of how the protein is spared or utilized, it emphasizes the importance of protein in the condition under discussion, and the rôle which carbohydrate may have in its conservation.

It would be unwise to generalize our findings. One might expect to find that the destructive action of all fat soluble hepatoxic agents would be affected by the amount of hepatic lipid. An adequate high carbohydrate diet, by virtue of its effect in lowering the hepatic lipid content, might decrease the incidence and severity of the damage to the liver. A high protein diet might be protective against the necrotic action of hepatic poisons, regardless of their fat solubility ; and carbohydrate administration, under conditions in which it spared protein might be consequently advantageous. Since the site and perhaps the mode of action of the various hepatoxic substances may differ, it would seem advisable to examine each one in the light of the above stated possibilities.

\section{CONCLUSIONS}

1. The incidence and the severity of damage to the hepatic cells, twenty-four hours after one hour of chloroform anesthesia, increases progressively with an increase in the concentration of lipids in the liver. This is independent of the content of glycogen in the liver at the beginning of the anesthesia. It may be modified by the protein content of the ration. The untoward effect of a previous high fat diet, under these circumstances, is explainable by the hypothesis suggested by Wells.

2. A high concentration of hepatic glycogen, per se, fails to confer any discernible protection against the hepatoxic action of chloroform, in rats with the same concentration of hepatic fatty acids, and similar intake of protein in the diet.

3 . The chief reason for the protection against hepatic injury following a diet high in carbohydrate content is probably the reduction in the 
lipid content of the liver which results from such a diet. Under certain conditions, i.e., inanition, administration of carbohydrate may very probably also protect the liver by virtue of its protein sparing action. There is no evidence that the depletion of hepatic glycogen by chloroform is associated with the metabolic requirements of the liver, but is probably a manifestation of an effect of the toxic agent.

4. A high protein diet, previous to the anesthesia with chloroform, markedly reduces the incidence of hepatic cellular necrosis, even in livers with a high lipid content, and, therefore, in the face of a severe attack by the chloroform. Regardless of whether this is due to a protection against injury in the first instance, or to a less intensive lesion due to a rapid regeneration, pari passu with the injury, it would seem to be best explained as being primarily the result of protein available to the liver as a result of the high protein intake.

5. Rats, starved for twenty-four hours prior to one hour of chloroform anesthesia, exhibit in almost all instances some degree of hepatic injury, largely necrosis. The incidence and degree of the damage is greater than in fed animals with the same content of hepatic lipid. Tentatively, it is suggested that the increased susceptibility of the starved rat is principally due to its depleted protein stores.

\section{BIBLIOGRAPHY}

1. Goldschmidt, S., Ravdin, I. S., and Lucké, B., The protective action of oxygen against the necrotizing effect of certain anesthetics on the liver. J. Pharmacol. and Exper. Therap., 1937, 59, 1.

2. Ravdin, I. S., Vars, H. M., Goldschmidt, S., and Klingensmith, $L$., The effect of anesthesia on the blood sugar, the liver glycogen, and liver fat. J. Pharmacol. and Exper. Therap., 1938, 64, 111.

3. (a) Opie, E. L., and Alford, L. B., The influence of diet on hepatic necrosis and toxicity of chloroform. J. A. M. A., 1914, 62, 895.

(b) Ibid. Diet and the hepatic lesions of chloroform, phosphorus, or alcohol. J. Exper. Med., 1915, 21, 1.

Diet and the nephritis caused by potassium chromate, uranium nitrate, or chloroform. J. Exper. Med., 1915, 21, 21.

4. Davis, N. C., and Whipple, G. H., The influence of fasting and various diets on the liver injury effected by chloroform anaesthesia. Arch. Int. Med., 1919, 23, 612.
5. (a) Moise, T. S., and Smith, A. H., The regeneration of liver tissue on various adequate diets. J. Exper. Med., 1924, 40, 13.

(b) Smith, A. H., and Moise, T. S., The regeneration of liver tissue during nutrition on inadequate diets and fasting. J. Exper. Med., 1924, 40, 209.

6. Minot, A. S., and Cutler, J. T., Guanidine retention and calcium reserve as antagonistic factors in carbon tetrachloride and chloroform poisoning. J. Clin. Invest., 1928, 6, 369.

Cutler, J. T., The accumulation of guanidine in the blood following acute liver injury by carbon tetrachloride, chloroform, arsenic or phosphorus. J. Pharmacol. and Exper. Therap., 1931, 41, 337.

7. (a) Rosenfeld, G., Zur Lehre von der Fettwanderung. Allegmeine Medicinishe Zentral Zeitung, 1900, No. 89, 1051.

(b) Ibid. Fettbildung. Ergebn. d. Physiol., 1903, 2, 50.

(c) Ibid. Der Process der Verfettung. Berl. Klin. Wchnschr., 1904, 41, 587.

(d) Ibid. Fett und Kohlenhydrate. Berl. Klin. Wchnschr., 1906, 43, 978.

(e) Ibid. Eiweiss Körper und Leberverfettung. Berl. Klin. Wchnschr., 1910, 47, 1268.

8. (a) Wells, H. G., Chemical Pathology. Saunders, Philadelphia, 1925, 5th ed., pp. 20 and 481.

(b) Ibid. Delayed chloroform poisoning and allied conditions. A note on the cause of the anatomic and clinical changes observed. J. A. M. A., 1906, 46, 341.

(c) Ibid. Chloroform necrosis of the liver. Arch. Int. Med., 1908, 1, 589.

9. Steenbock, H., A satisfactory ration for stock rats. Science, 1923, 58, 449.

10. Good, C. A., Kramer, H., and Somogyi, M., The determination of glycogen. J. Biol. Chem., 1933, 100, 485.

11. Peters, J. P., and Van Slyke, D. D., Quantitative Clinical Chemistry. Vol. II. Methods. Williams and Wilkins Co., Baltimore, 1932, p. 466.

12. Long, C. N. H., Personal communication.

13. Stoddard, J. L., and Drury, P. E., A titration method for blood fat. J. Biol. Chem., 1929, 84, 741.

14. Davis, N. C., The influence of diet upon the liver injury produced by carbon tetrachloride. J. Med. Res., 1924, 44, 601.

15. Guthrie, L. G., On the fatal effects of chloroform on children suffering from a peculiar condition of fatty liver. Lancet, 1903, 2, 10.

16. Beddard, A. P., A suggestion for treatment in delayed chloroform poisoning. Lancet, 1908, 1, 782.

17. Best, C. H., Huntsman, M. E., and Ridout, J. H., The "lipotropic" effect of protein. Nature, 1935, $135,821$.

Channon, H. J., and Wilkinson, H., Protein and the dietary production of fatty livers. Biochem. J., $1935,29,350$. 
Best, C. H., and Channon, H. J., The action of choline and other substances in the prevention and cure of fatty livers. Biochem. J., 1935, 29, 2651.

Best, C. H., Grant, R., and Ridout, J. H., The "lipotropic" effect of dietary protein. J. Physiol., 1936, 86, 337.

18. Luck, J. M., The question of protein storage. J. Biol. Chem., 1936, 115, 491.

19. Addis, T., Poo, I. J., and Lew, W., The quantities of protein lost by the various organs and tissues of the body during a fast. J. Biol. Chem., 1936, $115,111$.
Protein loss from liver during a two day fast. J. Biol. Chem., 1936, 115, 117.

20. Davis, N. C., Hall, C. C., and Whipple, G. H., The rapid construction of liver cell protein on a strict carbohydrate diet contrasted with fasting. Mechanism of protein sparing action of carbohydrate. Arch. Int. Med., 1919, 23, 689.

21. Daft, F. S., Robscheit-Robbins, F. S., and Whipple, G. H., Liver injury by chloroform, nitrogen metabolism, and conservation. Liver function and hemoglobin production in anemia. J. Biol. Chem., 1936, $113,391$. 